\title{
Sensory and Proximate Analysis of Value Added Bakery Products Using Bael (Aegle marmelos) and Stevia Powder
}

\author{
Amarjeet Kaur* and Anita Kochhar \\ Department of Food and Nutrition, College of Home Science, \\ Punjab Agricultural University, Ludhiana-141004, Punjab, India \\ *Corresponding author
}

\section{A B S T R A C T}

Keywords

Bael, Therapeutic,

Diabetes, Stevia

rebaudiana,

Calories.

\section{Article Info}

Accepted:

28 October 2017

Available Online:

10 December 2017
Aegle marmelos belongs to the family Rutaceae and is commonly called bael, bilwa, Bengal quince, vilvum, shriphal, etc. It is widely used for its medicinal and therapeutic properties. This fruit possesses many therapeutic properties including antidysentric, demulcent, astringent, antidiarrhoeal, anti-inflammatory and antipyretic activities. The constituents purified from this fruit are biologically active in fighting against several major diseases like diabetes, cancer and cardio vascular diseases. Stevia rebaudiana is a nutrient rich natural sweetest plant of Asteraceae family. Stevia is also known as sweet leaf, sweet herb, candy leaf, honey leaf and honey yerba. It is a magical plant which offers sweetness with no calories and do not show any side effects after consumption on human health.

\section{Introduction}

In the present scenario, great interest has been shown by the health professionals and public for use of traditional and indigenous medicinal plants in the prevention and treatment of various diseases. Many plants of the Rutaceae family are used since ancient times for a wide variety of ethnomedical properties possessed by this family. One of the member with immense medicinal properties is Aegle marmelose (L) found in India. It is also popular as bael or koovalam growing wild throughout deciduous forest of India, climbing to a height of $1,200 \mathrm{~m}$ in Western Himalayas. The plant contains a number of phytoconstituents like aegeline, agelinine, rutin, sterol sitosterol, -Dglucoside, marmesinine (1), lupeol, tannins, phlobatannins, flavonoids, umbelliferone, quercetin and volatile oils (Eugenol) and methyl eugenol) (2). The excessive sugar intakes have become a major health concern all over the world. Stevia is one such natural which is about 300 times sweeter than sucrose. It is a non-caloric or zero calorie natural sweetener isolated from the leaves of Stevia rebaudiana. It is quite popular as a sugar substitute in a wide range of foods and is used as a food supplement in China, Japan, Taiwan and South Korea. It does not only possess sweetening properties, but also have 
potential therapeutic value as a contraceptive, antihypertensive agent, antihyperglycemic agents by stimulating insulin secretion from pancreatic beta cells (3).

The glycosides present in stevia are stevioside and rebaudoside, which are 250-300 times sweeter than sucrose, heat stable, $\mathrm{pH}$ stable and non-fermentable. Stevia possesses many beneficial effects like helps in weight control, control of dental caries, in the management of diabetes, has anti-fungal and antibacterial properties, exerts a healing effect on blemishes and cuts, is useful in blood pressure management and aids immune modulation.

\section{Materials and Methods}

The bael fruit (var. Kaghzi), was procured from Regional Research Station, Patiala, Punjab. Bael pulp was cleaned to remove unwanted material and seeds. Bael fruit powder was prepared by drying the pulp in thin layers and dried to below four per cent moisture in a cabinet drier at $60 \pm 5^{\circ} \mathrm{C}$. Dried pulp pieces were ground to make a fine powder. The powder thus obtained was incorporated for development of value added products. Stevia powder was purchased from Ozzy Business Consulting Ltd, Patiala. All other ingredients like whole wheat flour, refined wheat flour, baking powder, powdered sugar etc. were procured from the local market of Ludhiana.

Development and standardization of value added products using bael and stevia powder

Two value added sweet bakery products i.e., atta biscuits and cup cake were developed and standardized using different combination of bael and stevia powder at different levels. The value added products were prepared in the food laboratory of department of Food and Nutrition, Punjab Agricultural University,
Ludhiana. The products were first standardized with different levels of bael powder. In second standardization, the sugar content of acceptable products with bael was then reduced and stevia powder was incorporated at different levels. To replace one gram of sugar, five milligram of stevia was added in all the value added sweet products.

\section{Atta biscuits}

Atta biscuits were standardized in two levels:

The recipe of the product with most acceptable level of bael powder and stevia powder

\section{Atta biscuits}

\section{Ingredients}

Wheat flour - 225g

Bael powder $-25 \mathrm{~g}$

Sugar - $120 \mathrm{~g}$

Stevia powder - 50mg

Fat (Dalda) - 135g

Baking powder $-1 / 4$ tsp

Sodium bicarbonate $-1 / 4$ tsp

Milk - 25ml

\section{Method}

Rubbed fat on a clean surface.

Gradually added sifted flour, bael powder, baking powder and sodium bicarbonate.

Sugar and stevia was added to it.

A smooth dough using milk was prepared.

Rolled the dough to $1 / 4$ inch thickness.

Cut into desired shape and baked at $150^{\circ} \mathrm{C}$ for 20 minutes. 


\section{Cup cake}

Cup cake was standardized at two levels:

The recipe of the product with most acceptable level has been given below:

\section{Cup cake}

\section{Ingredients}

Plain flour - $127.5 \mathrm{~g}$

Bael powder - $22.5 \mathrm{~g}$

Sugar - $110 \mathrm{~g}$

Stevia powder - 50mg

Butter - 100g

Baking powder - 1tsp

Baking soda $-1 / 2$ tsp

Milk powder - 50g

Milk - 150ml

\section{Method}

Mixed flour, bael, pulp powder, milk powder, baking soda, baking powder together and sieved it twice.

Creamed butter and sugar till light and fluffy.

Gently folded all the dry ingredients using cut and fold method.

Smooth dough of dropping consistency was prepared using milk.

Poured the mixture in greased and dusted muffin tray and levelled it properly.

Baked at $180^{\circ} \mathrm{C}$ for 40 minutes.

Cooled the cup cakes on a cooling rack.

\section{Sensory evaluation and proximate analysis}

The sensory evaluation of the developed products first trial was carried out by ten trained panelists including faculty of department of Food and Nutrition of Punjab Agricultural University while the second trial was evaluated by both the trained panel as well as diabetic panel using 9 point hedonic scale for attributes like appearance, colour, texture, flavour, taste and overall acceptability The highly acceptable products from the second trial containing both bael and stevia with their corresponding control (with no bael and stevia) were weighed, homogenized and oven dried at $60^{\circ} \mathrm{C}$. Dried samples were stored in air tight plastic bags for further analysis. Proximate analysis was done using the standard (4) methods.

\section{Statistical analysis}

Mean and standard error for different parameters were computed. Kruskal Wallis test was used for selecting the best formulations through sensory evaluation. $\mathrm{T}$ test was applied to compare the nutritional parameters between the control and the value added products. The data was analyzed using appropriate statistical tools.

\section{Results and Discussion}

\section{Sensory evaluation of value added bakery} products with bael and stevia powder

\section{Atta biscuits incorporated with bael powder}

Different treatments of biscuits were prepared using bael powder. $\mathrm{C}$ was taken as control which was prepared using wheat flour. Treatments B1 to B4 were prepared using bael powder at levels 5, 10, 15 and 20 per cent respectively. Different scores were obtained for the different treatments as presented in Table 5. Control scored lower than B2 for the sensory parameters of colour, flavor and taste with an overall acceptability score of 7.79. Among the treatments with added bael powder, B2 (10 per cent bael powder) scored the highest and was then selected as the control for the second 
standardization of biscuits with stevia powder. The difference in scores was found to be statistically significant with regard to all the sensory parameters for all the treatments. The highest mean scores for taste and texture of biscuits were observed for treatment B2 followed by control. With respect to colour and flavour, the score of 7.6 and 7.7 respectively was at par for control and B3 treatment. Among the treatments prepared bael powder, B4 (20 per cent bael powder) received the least scores for all the parameters with an overall acceptability of 7.38. (5) reported that incorporation of deoiled peanut flour in biscuits was most acceptable at 5 per cent (8.60) and was acceptable upto 15 per cent but more amounts had a negative effect. Similar results have been reported by (6).

Biscuits were highly acceptable with an incorporation of 10 per cent defatted peanut flour with good nutritional profile. Cookies incorporated with moong bean and chickpea flour at 10-20 percent level were found to be highly acceptable by panelists of all age groups (7). Cookies were developed incorporating full fat soy flour at different levels with wheat flour by (8). The authors found out that the cookies were highly acceptable at 30 and 50 per cent levels of addition of soy flour to wheat flour (Table 1).

Atta biscuits incorporated with bael and stevia powder by semi-trained panel

Five different treatments of biscuits were prepared using 10 per cent bael powder and different proportions of stevia powder as a source of zero calorie sweetener. C was taken as control which was prepared using 90 per cent wheat flour and 10 per cent bael powder. Treatments BS1 to BS4 were prepared incorporating stevia powder at levels $8,12,16$ and 20 per cent respectively. The difference in scores was found to be statistically significant with regard to all the sensory parameters as shown in Table 6 and Figure 1. The highest mean scores for different sensory parameters of biscuits were observed for BS1 followed by control. The scores for appearance were higher for control as compared to all the treatments. Among the treatments prepared using stevia powder, BS4 received the least scores for all the parameters with an overall acceptability of 6.5. The highest mean score for texture, flavor and taste was attained by BS1 treatment which is significantly different with regards to various treatments. Hence, biscuits of BS1 treatment were selected as the final value added product for further analysis (Table 2).

\section{Atta Biscuits incorporated with bael and stevia powder by diabetics}

The mean scores of acceptability trials of atta biscuits by 10 diabetic panellists on ninepoint hedonic rating scale are presented in Table 7. The results revealed that the highest scores for all the sensory parameters among test samples were obtained by BS3 treatment (8 per cent stevia added). The overall acceptability of BS1 treatment was found to be higher i.e. 7.55 than control and other treatments. The overall acceptability of control i.e. 6.69 was found to be lower than all the treatments except for BS4. The highest score for colour, texture, flavour and taste were observed for BS1 which showed a significant difference between control and different treatments. Statistical results revealed that there was significant difference between the BS1 treatment and control sample for appearance, colour, texture, flavour and taste and also among the treatments. Utilization of stevia extract in biscuits showed a non-significant difference on rheological or organoleptic properties between control and treated samples when adding stevioside at the levels of $0.025,0.05$, 0.075 and 0.1 per cent of wheat flour (9). 


\section{Cup cake incorporated with bael powder}

Different treatments of cup cake were prepared using bael powder. $\mathrm{C}$ was taken as control which was prepared using plain flour. Treatments B1 to B4 were prepared using bael powder at levels 10, 15, 20 and 25 per cent respectively. Scores obtained for the different treatments are presented in Table 8. Control (7.98) scored the highest overall acceptability scores among all the samples followed by B2 (7.89) and B1 (7.78). Among the treatments with added bael powder, B2 (15 per cent bael powder) scored the highest overall acceptability scores and was then selected as the control for the second standardization of cup cake with stevia powder. The difference in scores was found to be statistically significant with regard to all the sensory parameters for all the treatments. The highest mean scores for appearance, colour and texture of cup cake were observed for control followed by treatment B2. With respect to flavor the score of 8.0 was at par for Control, B1 and B2 treatments. The highest mean scores for taste was received by B2 i.e., 7.95 followed by B1 i.e., 7.9 and C i.e., 7.8. Among the treatments prepared B4 (25 per cent bael powder) received the least scores for all the parameters with an overall acceptability of 6.53. Statistical analysis showed a significant difference between all the sensory parameters among all the treatments. The mean scores for flavor (8.0) and taste (7.95) for treatment B2 were found to be significantly higher than rest of the treatments (Table 3 and 4).

\section{Cup cake incorporated with bael and stevia powder by semi-trained panel}

Cup cake with different levels of stevia powder were developed and standardized along with addition of bael powder from the first standardization. Control (C) sample was the acceptable treatment from the first standardization, prepared using bael powder and plain flour in a ratio of 15:85. Other four levels were prepared with addition of 8,16 , 24 and 66.5 per cent of stevia powder designated as BS1 to BS4 respectively. The treatments were then subjected to sensory evaluation by the semi trained panel to select the acceptable level of stevia powder in cup cake. The mean scores of acceptability trials of cupcake with different levels of stevia powder are presented in Table 9 and Figure 2. The treatment BS1 obtained the highest score with regard to all the sensory parameters except for appearance and texture. The highest mean scores for overall acceptability of cup cake was found to be 7.88 , followed by $\mathrm{C}$ (7.76) and BS2 (7.74). The mean scores for colour for $\mathrm{C}$ and BS1 were observed to be at par. Statistical analysis revealed a significant difference in all the treatments for all the sensory parameters. The scores for colour, taste and overall acceptability for BS1 were significantly higher than control and other treatments.

\section{Cup cake incorporated with bael and stevia powder by diabetics}

Table 10 presented the mean scores for acceptability of cup cake incorporated with $15 \%$ bael powder and different levels of stevia by the diabetic panel. The overall acceptability score ranged from 7.34 to 7.7 as depicted in table 10 . The highest overall acceptability score was gained by BS2 containing $16 \%$ stevia followed by BS1 (8\% stevia $+92 \%$ sugar) and Control. The lowest score for the same was scored by BS4. The statistical analysis revealed that the sensory scores for appearance, colour, texture, flavor and taste were non-significantly higher for the treatments of cupcake incorporated with stevia for treatment B3. BS1 scored a nonsignificantly higher score for taste among all the treatments followed by $\mathrm{BS} 2$. The mean taste scores for $\mathrm{C}$ and $\mathrm{BS} 1$ were at par. 
Table.1 Atta Biscuits using different levels of bael powder

\begin{tabular}{|l|c|c|c|c|c|}
\hline \multirow{2}{*}{ Ingredients } & \multicolumn{5}{|c|}{ Atta Biscuits } \\
\cline { 2 - 6 } & C & B1 & B2 & B3 & B4 \\
\hline Wheat flour $(\mathrm{g})$ & 250 & 237.5 & 225 & 212.5 & 200 \\
\hline Bael powder $(\mathrm{g})$ & -- & 12.5 & 25 & 37.5 & 50 \\
\hline Sugar $(\mathrm{g})$ & 130 & 130 & 130 & 130 & 130 \\
\hline Fat $($ Dalda) $(\mathrm{g})$ & 135 & 135 & 135 & 135 & 135 \\
\hline Baking powder & $1 / 4 \mathrm{tsp}$ & $1 / 4 \mathrm{tsp}$ & $1 / 4 \mathrm{tsp}$ & $1 / 4 \mathrm{tsp}$ & $1 / 4 \mathrm{tsp}$ \\
\hline Sodium bicarbonate & $1 / 4 \mathrm{tsp}$ & $1 / 4 \mathrm{tsp}$ & $1 / 4 \mathrm{tsp}$ & $1 / 4 \mathrm{tsp}$ & $1 / 4 \mathrm{tsp}$ \\
\hline Milk $(\mathrm{ml})$ & 25 & 25 & 25 & 25 & 25 \\
\hline
\end{tabular}

$\mathrm{C}-$ Control (100\% wheat flour)

B1-5\% bael powder B2-10\% bael powder B3-15\% bael powder B4-20\%bael powder

Table.2 Atta biscuits using acceptable level of bael powder and different levels of stevia powder

\begin{tabular}{|l|c|c|c|c|c|}
\hline \multirow{2}{*}{ Ingredients } & \multicolumn{5}{|c|}{ Atta biscuits } \\
\cline { 2 - 6 } & C & BS1 & BS2 & BS3 & BS4 \\
\hline Wheat flour $(\mathrm{g})$ & 225 & 225 & 225 & 225 & 225 \\
\hline Bael powder $(\mathrm{g})$ & 25 & 25 & 25 & 25 & 25 \\
\hline Sugar $(\mathrm{g})$ & 130 & 120 & 115 & 110 & 105 \\
\hline Stevia $(\mathrm{mg})$ & -- & 50 & 75 & 100 & 125 \\
\hline Fat (Dalda) $(\mathrm{g})$ & 135 & 135 & 135 & 135 & 135 \\
\hline Baking powder & $1 / 4 \mathrm{tsp}$ & $1 / 4 \mathrm{tsp}$ & $1 / 4 \mathrm{tsp}$ & $1 / 4 \mathrm{tsp}$ & $1 / 4 \mathrm{tsp}$ \\
\hline Sodium bicarbonate & $1 / 4 \mathrm{tsp}$ & $1 / 4 \mathrm{tsp}$ & $1 / 4 \mathrm{tsp}$ & $1 / 4 \mathrm{tsp}$ & $1 / 4 \mathrm{tsp}$ \\
\hline Milk $(\mathrm{ml})$ & 25 & 25 & 25 & 25 & 25 \\
\hline
\end{tabular}

$\mathrm{C}$ - Control (90\% whole wheat flour+ $10 \%$ bael powder+100\% sugar)

BS1- $8 \%$ stevia $+92 \%$ sugar BS2-12\% stevia $+88 \%$ sugar BS3- $16 \%$ stevia $+84 \%$ sugar

BS4- $20 \%$ stevia $+80 \%$ sugar

Table.3 Cup cake using different levels of bael powder

\begin{tabular}{|l|c|c|c|c|c|}
\hline \multirow{2}{*}{ Ingredients } & \multicolumn{5}{|c|}{ Cup cake } \\
\cline { 2 - 6 } & C & B1 & B2 & B3 & B4 \\
\hline Plain flour $(\mathrm{g})$ & 150 & 135 & 127.5 & 120 & 112.5 \\
\hline Bael powder $(\mathrm{g})$ & -- & 15 & 22.5 & 30 & 37.5 \\
\hline Sugar $(\mathrm{g})$ & 120 & 120 & 120 & 120 & 120 \\
\hline Butter $(\mathrm{g})$ & 100 & 100 & 100 & 100 & 100 \\
\hline Baking powder & 1 tsp & 1 tsp & 1 tsp & 1 tsp & 1 tsp \\
\hline Baking soda & $1 / 2$ tsp & $1 / 2$ tsp & $1 / 2$ tsp & $1 / 2$ tsp & $1 / 2$ tsp \\
\hline Milk powder $(\mathrm{g})$ & 50 & 50 & 50 & 50 & 50 \\
\hline Milk (ml) & 150 & 150 & 150 & 150 & 150 \\
\hline
\end{tabular}

$\mathrm{C}-$ Control (100\% plain flour)

B1- 10\% bael powder B2- 15\% bael powder B3-20\% bael powder B4- 25\% bael powder 
Table.4 Cup cake using acceptable level of bael powder and different levels of stevia

\begin{tabular}{|l|c|c|c|c|c|}
\hline \multirow{2}{*}{ Ingredients } & \multicolumn{5}{|c|}{ Cup cake } \\
\cline { 2 - 6 } & C & BS1 & BS2 & BS3 & BS4 \\
\hline Plain flour (g) & 127.5 & 127.5 & 127.5 & 127.5 & 127.5 \\
\hline Bael powder (g) & 22.5 & 22.5 & 22.5 & 22.5 & 22.5 \\
\hline Sugar (g) & 120 & 110 & 100 & 90 & 80 \\
\hline Stevia (mg) & -- & 50 & 100 & 150 & 200 \\
\hline Butter (g) & 100 & 100 & 100 & 100 & 100 \\
\hline Baking powder & $1 \mathrm{tsp}$ & $1 \mathrm{tsp}$ & $1 \mathrm{tsp}$ & $1 \mathrm{tsp}$ & $1 \mathrm{tsp}$ \\
\hline Baking soda & $1 / 2 \mathrm{tsp}$ & $1 / 2 \mathrm{tsp}$ & $1 / 2 \mathrm{tsp}$ & $1 / 2 \mathrm{tsp}$ & $1 / 2 \mathrm{tsp}$ \\
\hline Milk powder (g) & 50 & 50 & 50 & 50 & 50 \\
\hline Milk (ml) & 150 & 150 & 150 & 150 & 150 \\
\hline
\end{tabular}

C - Control (85\% plain flour+ $15 \%$ bael powder+100\% sugar)

BS1- $8 \%$ stevia $+92 \%$ sugar BS2-16\% stevia $+84 \%$ sugar BS3- $24 \%$ stevia $+76 \%$ sugar

BS4- $32 \%$ stevia $+68 \%$ sugar

Table.5 Mean sensory scores for atta biscuits incorporated with bael powder

\begin{tabular}{|c|c|c|c|c|c|c|}
\hline \multirow{2}{*}{ Samples } & \multicolumn{7}{|c|}{ Parameters } \\
\cline { 2 - 7 } & Appearance & Colour & Texture & Flavour & Taste & Overall acceptability \\
\hline C & 7.9 & 7.6 & 8 & 7.7 & 7.75 & 7.79 \\
\hline B1 & 7.65 & 7.6 & 7.6 & 7.6 & 7.5 & 7.6 \\
\hline B2 & 7.8 & 8 & 7.8 & 7.85 & 7.9 & 7.87 \\
\hline B3 & 7.3 & 7.6 & 7.5 & 7.7 & 7.4 & 7.5 \\
\hline B4 & 7.6 & 7.5 & 7.3 & 7.4 & 7.1 & 7.38 \\
\hline$\chi^{2}$ & $16.509 * *$ & $25.254 * *$ & $26.709 * *$ & $18.939 * *$ & $27.308 * *$ & $31.808 * *$ \\
\hline
\end{tabular}

** Significant at $1 \%$ level of significance $(\mathrm{p}<0.01) \quad$ NS - Non significant

*Significant at $5 \%$ level of significance ( $\mathrm{p}<0.05) \quad \mathrm{C}-$ Control (100\% wheat flour)

B1- 5\% bael powder B2- $10 \%$ bael powder B3- $15 \%$ bael powder B4- $20 \%$ bael powder

Table.6 Mean sensory scores for atta biscuits incorporated with bael and stevia powder by semi trained panel

\begin{tabular}{|c|c|c|c|c|c|c|}
\hline \multirow{2}{*}{ Samples } & \multicolumn{6}{|c|}{ Parameters } \\
\cline { 2 - 7 } & Appearance & Colour & Texture & Flavour & Taste & Overall acceptability \\
\hline C & 7.5 & 7.5 & 7.4 & 7.3 & 7.3 & 7.4 \\
\hline BS1 & 7.3 & 7.7 & 7.5 & 7.6 & 7.6 & 7.54 \\
\hline BS2 & 6.8 & 6.8 & 6.9 & 6.8 & 6.8 & 7.34 \\
\hline BS3 & 6.4 & 6.5 & 6.6 & 6.6 & 6.55 & 6.59 \\
\hline BS4 & 6.3 & 6.4 & 6.5 & 6.5 & 6.5 & 6.5 \\
\hline$\chi^{2}$ & $19.407 * *$ & $22.488^{*} *$ & $16.190 * *$ & $18.100 * *$ & $19.216 * *$ & $23.507 * *$ \\
\hline
\end{tabular}

** Significant at $1 \%$ level of significance $(\mathrm{p}<0.01) \quad$ NS - Non significant

$*$ Significant at $5 \%$ level of significance $(\mathrm{p}<0.05)$

C - Control (90\% whole wheat flour $+10 \%$ bael powder $+100 \%$ sugar)

BS1- $8 \%$ stevia $+92 \%$ sugar BS2-12\% stevia $+88 \%$ sugar BS3- $16 \%$ stevia $+84 \%$ sugar

BS4- $20 \%$ stevia $+80 \%$ sugar 
Table.7 Mean sensory scores for atta biscuits incorporated with bael and stevia powder by diabetics

\begin{tabular}{|c|c|c|c|c|c|c|}
\hline \multirow{2}{*}{ Samples } & \multicolumn{7}{|c|}{ Parameters } \\
\cline { 2 - 7 } & Appearance & Colour & Texture & Flavour & Taste & Overall acceptability \\
\hline C & 6.5 & 6.7 & 6.7 & 6.7 & 6.55 & 6.69 \\
\hline BS1 & 7.6 & 7.9 & 7.6 & 7.8 & 7.8 & 7.74 \\
\hline BS2 & 7 & 7 & 7.1 & 7 & 7.05 & 7.34 \\
\hline BS3 & 7.7 & 7.7 & 7.4 & 7.55 & 7.4 & 7.55 \\
\hline BS4 & 6 & 6 & 5 & 7 & 6 & 6 \\
\hline$\chi^{2}$ & $25.694 * *$ & $32.062 * *$ & $17.327 * *$ & $26.474 * *$ & $26.124 * *$ & $26.600^{* *}$ \\
\hline
\end{tabular}

** Significant at $1 \%$ level of significance $(\mathrm{p}<0.01) \quad$ NS - Non significant

$*$ Significant at $5 \%$ level of significance $(\mathrm{p}<0.05)$

$\mathrm{C}-$ Control $(90 \%$ whole wheat flour $+10 \%$ bael powder $+100 \%$ sugar)

BS1- $8 \%$ stevia $+92 \%$ sugar BS2-12\% stevia $+88 \%$ sugar BS3-16\% stevia $+84 \%$ sugar

BS4- $20 \%$ stevia $+80 \%$ sugar

Table.8 Mean sensory scores for Cup cake incorporated with bael powder

\begin{tabular}{|c|c|c|c|c|c|c|}
\hline \multirow{2}{*}{ Samples } & \multicolumn{7}{|c|}{ Parameters } \\
\cline { 2 - 7 } & Appearance & Colour & Texture & Flavour & Taste & Overall acceptability \\
\hline C & 7.9 & 8.1 & 8.1 & 8 & 7.8 & 7.98 \\
\hline B1 & 7.6 & 7.5 & 7.9 & 8 & 7.9 & 7.78 \\
\hline B2 & 7.8 & 7.9 & 7.8 & 8 & 7.95 & 7.89 \\
\hline B3 & 7.5 & 7.8 & 8 & 7.7 & 7.6 & 7.72 \\
\hline B4 & 6.6 & 6.5 & 6.6 & 6.65 & 6.3 & 6.53 \\
\hline$\chi^{2}$ & $15.921^{*} *$ & $18.952^{* *}$ & $21.252^{* *}$ & $21.953^{* *}$ & $26.496 * *$ & $21.707 * *$ \\
\hline
\end{tabular}

** Significant at $1 \%$ level of significance $(\mathrm{p}<0.01)$

* Significant at $5 \%$ level of significance $(\mathrm{p}<0.05)$

NS - Non significant

B1- $10 \%$ pulp powder B2- 15\% pulp powder B3- $20 \%$ pulp powder B4- 25\% pulp powder

Table.9 Mean sensory scores for Cup cake incorporated with bael and stevia powder by semi trained panel

\begin{tabular}{|c|c|c|c|c|c|c|}
\hline \multirow{2}{*}{ Samples } & \multicolumn{6}{|c|}{ Parameters } \\
\cline { 2 - 7 } & Appearance & Colour & Texture & Flavour & Taste & $\begin{array}{c}\text { Overall } \\
\text { acceptability }\end{array}$ \\
\hline C & 8 & 7.9 & 7.7 & 7.6 & 7.6 & 7.76 \\
\hline BS1 & 7.9 & 7.9 & 7.6 & 7.9 & 8.1 & 7.88 \\
\hline BS2 & 7.7 & 7.7 & 7.6 & 8 & 7.7 & 7.74 \\
\hline BS3 & 6.4 & 6.3 & 6.2 & 6 & 6.2 & 6.22 \\
\hline BS4 & 6.3 & 6.3 & 6.1 & 5.7 & 6 & 6.08 \\
\hline$\chi^{2}$ & $39.522^{* *}$ & $34.640^{* *}$ & $32.696^{* *}$ & $40.169^{* *}$ & $37.601 * *$ & $36.816^{* *}$ \\
\hline
\end{tabular}

** Significant at $1 \%$ level of significance $(\mathrm{p}<0.01) \quad$ NS - Non significant

*Significant at $5 \%$ level of significance $(\mathrm{p}<0.05)$

C - Control ( $85 \%$ plain flour $+15 \%$ bael powder $+100 \%$ sugar)

BS1- 8\% stevia + 92\% sugar BS2-16\% stevia $+84 \%$ sugar BS3- $24 \%$ stevia $+76 \%$ sugar

BS4- $32 \%$ stevia $+68 \%$ sugar 
Table.10 Mean sensory scores for cup cake incorporated with bael and stevia powder by diabetics

\begin{tabular}{|c|c|c|c|c|c|c|}
\hline \multirow{2}{*}{ Samples } & \multicolumn{6}{|c|}{ Parameters } \\
\cline { 2 - 7 } & Appearance & Colour & Texture & Flavour & Taste & $\begin{array}{c}\text { Overall } \\
\text { acceptability }\end{array}$ \\
\hline C & 7.5 & 7.5 & 7.4 & 7.4 & 7.4 & 7.44 \\
\hline BS1 & 7.5 & 7.5 & 7.7 & 7.5 & 8 & 7.64 \\
\hline BS2 & 7.5 & 7.7 & 7.7 & 7.9 & 7.7 & 7.7 \\
\hline BS3 & 7.5 & 7.65 & 7.3 & 7.3 & 7.35 & 7.42 \\
\hline BS4 & 7.2 & 7.4 & 7.3 & 7.4 & 7.4 & 7.34 \\
\hline$\chi^{2}$ & $1.826^{\mathrm{NS}}$ & $1.150^{\mathrm{NS}}$ & $3.931^{\mathrm{NS}}$ & $5.813^{\mathrm{NS}}$ & $9.124^{\mathrm{NS}}$ & $6.043^{\mathrm{NS}}$ \\
\hline
\end{tabular}

** Significant at $1 \%$ level of significance $(\mathrm{p}<0.01) \quad$ NS - Non significant

$*$ Significant at $5 \%$ level of significance $(\mathrm{p}<0.05)$

$\mathrm{C}-$ Control ( $85 \%$ plain flour+ $15 \%$ bael powder+100\% sugar)

BS1- $8 \%$ stevia $+92 \%$ sugar BS2-16\% stevia $+84 \%$ sugar BS3- $24 \%$ stevia $+76 \%$ sugar

BS4- $32 \%$ stevia $+68 \%$ sugar

Table.11 Proximate composition of the value added bakery products

\begin{tabular}{|c|c|c|c|c|c|c|c|}
\hline Products & $\begin{array}{c}\text { Moisture } \\
(\%)\end{array}$ & $\begin{array}{c}\text { Crude } \\
\text { Protein } \\
(\%)\end{array}$ & $\begin{array}{c}\text { Crude Fat } \\
(\%)\end{array}$ & $\begin{array}{c}\text { Total Ash } \\
(\%)\end{array}$ & $\begin{array}{c}\text { Crude } \\
\text { Fiber }(\%)\end{array}$ & $\begin{array}{c}\text { Carbohydrate } \\
\text { (\%) (by } \\
\text { differences) }\end{array}$ & $\begin{array}{c}\text { Energy } \\
\text { (Kcal/100g) }\end{array}$ \\
\hline $\begin{array}{l}\text { Atta Biscuits } \\
\text { (control) }\end{array}$ & $4.78 \pm 0.10$ & $9.52 \pm 0.28$ & $23.12 \pm 0.48$ & $1.21 \pm 0.06$ & $0.65 \pm 0.05$ & $62.11 \pm 0.27$ & $490.96 \pm 0.02$ \\
\hline Acceptable & $5.07 \pm 0.16$ & $8.40 \pm 0.31$ & $20.61 \pm 0.06$ & $1.43 \pm 0.04$ & $0.95 \pm 0.03$ & $63.56 \pm 0.30$ & $472.67 \pm 0.88$ \\
\hline t-value & $1.56^{\mathrm{NS}}$ & $2.72 *$ & $4.91 * *$ & $3.01 *$ & $4.73 * *$ & $3.53 *$ & $20.74 * *$ \\
\hline $\begin{array}{l}\text { CupCake } \\
\text { (control) }\end{array}$ & $23.50 \pm 0.30$ & $9.94 \pm 0.07$ & $16.61 \pm 0.19$ & $2.04 \pm 0.03$ & $1.05 \pm 0.15$ & $46.87 \pm 0.54$ & $376.77 \pm 0.95$ \\
\hline Acceptable & $26.91 \pm 0.57$ & $9.17 \pm 0.11$ & $14.78 \pm 0.56$ & $2.08 \pm 0.05$ & $2.36 \pm 0.39$ & $44.69 \pm 0.21$ & $348.31 \pm 3.89$ \\
\hline t-value & $5.27 * *$ & $5.81 * *$ & $3.07 *$ & $0.79^{\mathrm{NS}}$ & $3.11^{*}$ & $3.79 *$ & $7.11^{* *}$ \\
\hline
\end{tabular}

Values are given as Mean \pm SE*Significant at $5 \%$ level of significance $(p<0.05)$

$* *$ Significant at $1 \%$ level of significance $(p<0.01)$ NS- Non significant

Table.12 Mineral content of value added bakery products

\begin{tabular}{|l|c|c|c|c|c|c|}
\hline Products & $\begin{array}{c}\text { Calcium } \\
(\mathbf{m g} / \mathbf{1 0 0 g})\end{array}$ & $\begin{array}{c}\text { Phosphorus } \\
(\mathbf{m g} / \mathbf{1 0 0 g})\end{array}$ & $\begin{array}{c}\text { Iron } \\
(\mathbf{m g} / \mathbf{1 0 0 g})\end{array}$ & $\begin{array}{c}\text { Zinc } \\
(\mathbf{m g} / \mathbf{1 0 0 g})\end{array}$ & $\begin{array}{c}\text { Potassium } \\
(\mathbf{m g} / \mathbf{1 0 0 g})\end{array}$ & $\begin{array}{c}\text { Sodium } \\
(\mathbf{m g} / \mathbf{1 0 0 g})\end{array}$ \\
\hline Biscuit (control) & $27.32 \pm 0.48$ & $114.33 \pm 3.03$ & $2.73 \pm 0.04$ & $1.66 \pm 0.05$ & $117.21 \pm 1.02$ & $13.41 \pm 0.24$ \\
\hline Acceptable & $25.06 \pm 0.17$ & $109.70 \pm 1.20$ & $2.57 \pm 0.06$ & $1.15 \pm 0.03$ & $136.31 \pm 0.65$ & $12.49 \pm 0.14$ \\
\hline t-value & $4.34^{*}$ & $1.42^{\mathbf{N S}}$ & $2.11^{\mathbf{N S}}$ & $8.24^{* *}$ & $5.86^{* *}$ & $3.31^{*}$ \\
\hline $\begin{array}{l}\text { CupCake } \\
\text { (control) }\end{array}$ & $86.25 \pm 0.60$ & $160.72 \pm 0.28$ & $1.53 \pm 0.03$ & $0.30 \pm 0.03$ & $85.84 \pm 0.27$ & $25.19 \pm 0.46$ \\
\hline Acceptable & $86.42 \pm 0.25$ & $159.81^{\mathbf{N S}} \mathbf{2 9}$ & $1.33 \pm 0.04$ & $0.28 \pm 0.01$ & $96.15 \pm 0.46$ & $23.04 \pm 0.14$ \\
\hline t-value & $0.26^{\mathbf{N S}}$ & $2.27^{\mathbf{N S}}$ & $3.84^{*}$ & $0.41^{\mathbf{N S}}$ & $19.37^{* *}$ & $4.45^{*}$ \\
\hline
\end{tabular}


Table.13 Vitamin C and total carotene content of value added bakery products

\begin{tabular}{|l|c|c|}
\hline Products & Vitamin C (mg) & Carotene $(\boldsymbol{\mu g})$ \\
\hline Atta Biscuits (control) & $0.04 \pm 0.00$ & $20.63 \pm 0.23$ \\
\hline Acceptable & $0.25 \pm 0.01$ & $116.64 \pm 4.87$ \\
\hline t-value & $3.94 *$ & $2.42^{\mathrm{NS}}$ \\
\hline Cup Cake (control) & $1.03 \pm 0.11$ & $7.94 \pm 0.31$ \\
\hline Acceptable & $2.95 \pm 0.03$ & $9.31 \pm 0.22$ \\
\hline t-value & $16.59 * *$ & $3.57^{*}$ \\
\hline
\end{tabular}

Values are given as Mean \pm SE*Significant at $5 \%$ level of significance $(p<0.05)$

$* *$ Significant at $1 \%$ level of significance $(p<0.01)$ NS- Non significant

Fig.1 Mean sensory scores for atta biscuits incorporated with bael and stevia powder by semi trained panel

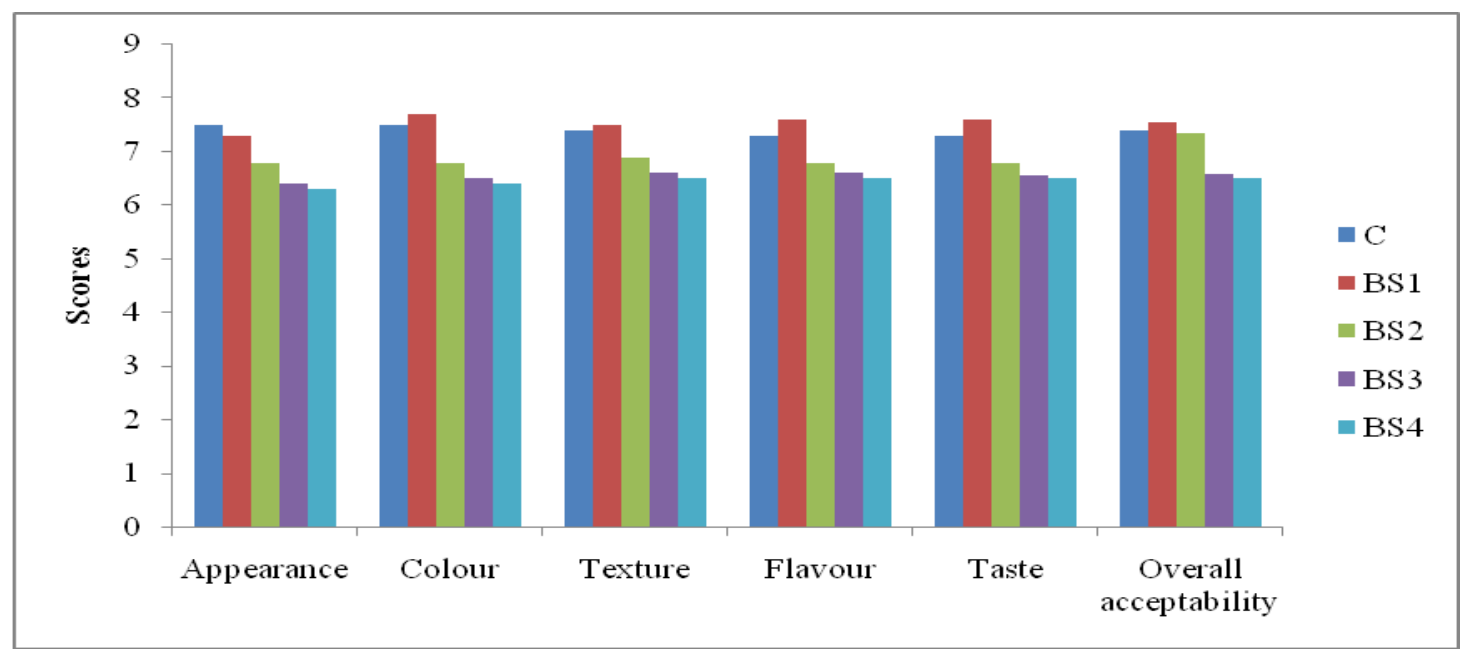

Fig.2 Mean sensory scores for Cup cake incorporated with bael and stevia powder by semi trained panel

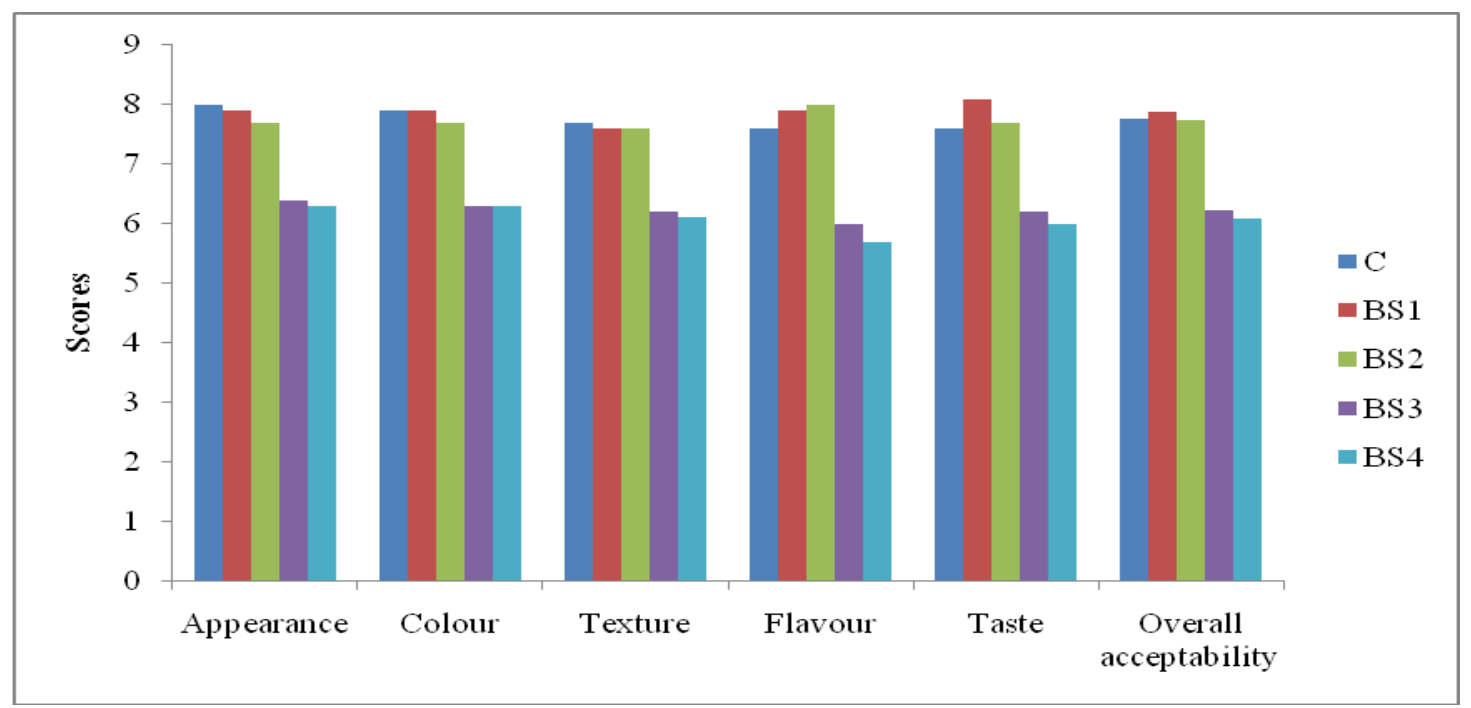


Proximate composition of value added bakery products

\section{Atta Biscuits}

The results for proximate composition of atta biscuits is given in Table 11. The moisture content of BS2 was observed to be nonsignificant higher than $\mathrm{C}$ i.e., 5.07 and 4.78 per cent respectively. A significant decrease in protein content of BS2 i.e., 8.40 per cent was seen as compared to C i.e., (9.52\%) which can be attributed to decreasing the ratio of wheat flour for incorporating bael powder $(\mathrm{p}<0.05)$. Crude fat content of BS2 and C was observed to be 20.61 and 23.12 per cent respectively which is significantly lower for BS2 $(\mathrm{p}<0.01)$. There was a significant increase in total ash $(1.43 \%)$ and crude fibre content $(0.95 \%)$ in $\mathrm{BS}$ as compared to $\mathrm{C}$ i.e. 1.21 and 0.65 per cent respectively $(p<0.05)$.The carbohydrate content of BS2 i.e. 52.72 per cent was observed to be significantly lower than that of $\mathrm{C}$ i.e. $52.72 \%$ $(p<0.01)$. A significant decrease in energy content of BS treatment in comparison to $\mathrm{C}$ was observed i.e. 472.67 and $490.96 \mathrm{Kcal}$ respectively (Fig. 1 and 2). A significant difference was observed in all the parameters of proximate composition except for moisture.

\section{Cup cake}

The proximate composition of control and BS1 of cup cake is given in Table 11. For all the parameters of proximate composition the difference between $\mathrm{C}$ and test sample was found to be statistically significant except for total ash content. The moisture content of $\mathrm{C}$ and BS1 was 23.50 and 26.91 per cent respectively with a significant difference $(\mathrm{p}<0.01)$. The crude protein content of control $(9.97 \%)$ was significantly higher than BS1 i.e. 9.17\% ( $\mathrm{p}<0.01)$. A significant decrease in fat content of BS1 (14.78\%) was observed as compared to i.e. $16.61 \quad(\mathrm{p}<0.05)$. A nonsignificant increase in ash content was observed for BS1 i.e. 2.08\% as compared to 2.04 per cent in C. A significant increase in crude fibre content was observed for BS2 $(2.36 \%)$ as compared to $\mathrm{C}(1.05 \%)(\mathrm{p}<0.05)$ carbohydrate content of BS i.e. $44.69 \%$ decreased significantly with respect to $C$ i.e. $46.87(\mathrm{p}<0.05)$. A significant decrease in energy content of BS1 i.e. $348.7 \mathrm{kcal}$ was observed as compared to C i.e. $376.77 \mathrm{Kcal}$ as shown in Figure 1 and $2(\mathrm{p}<0.01)$.

A low but significantly different increase in vitamin $\mathrm{C}$ content of test samples was observed as compared to control as represented in Table 13. Carotene content increased significantly in test samples of cup cake. Increase in carotene content of atta biscuits was found to be of non-significant difference.

Calcium content value added bakery products is presented in Table 12. The total calcium content of test samples was found to be 25.06 for atta biscuits and $86.42 \mathrm{mg} / 100 \mathrm{gm}$ for cup cake. The increase in calcium content of cupcake in the test sample was observed to be statistically non-significant as compared to control. Increase in calcium content of atta biscuits in test samples was found to be of significant difference $(\mathrm{p}<0.05)$. A nonsignificant decrease in phosphorous content of test samples was observed cup cake and atta biscuits. Zinc content was found to be quite low in control as well as test samples. A nonsignificant increase in iron content of atta biscuits. The iron content of cupcake was found to be $1.53 \mathrm{mg} / 100 \mathrm{~g}$ respectively for control while for test samples it was found to be $1.33 \mathrm{mg} / 100 \mathrm{~g}$. This increase in iron control in comparison to test sample was found to be significantly different $(\mathrm{p}<0.05)$. The potassium content of developed value added bakery products showed the significant increase as compared to control. The sodium 
content of cupcake and atta biscuits, for test samples as compared to control was found to be of significant difference

Bael (aegle marmelos) is an underutilized fruit which has a lot of potential to be used in the food processing industry for value addition in various products. Therapeutic properties of this fruit are a well-known fact. Incorporation of bael pulp powder along with stevia to decrease the calorie content of the developed bakery products is an initiative to use this medicinal fruit and stevia for nutritional and health benefits of the society. The health and functional foods prepared from bael and stevia is still need to be explored and more research work need to be investigated to make better use of these natural herbal plants.

\section{References}

1. Sharma BR, Rattan RK, Sharma P. 1980. Constituent of leaves and fruits of Aegle marmelos. Indian J. Chem. 19B, 162.

2. Banerjee A, Nigam SS. 1979). Studies on the fixed oil from the seeds of Aegle marmelos Corr. J.Am. Oil Chem. Soc., 56: 647.

3. Jeppensen P B, Gregersen S, Poulsen C K and Hermansen K. 2000. Stevioside acts directly on the pancreatic beta cells to secrete insulin: action independent of cyclic adenosine monophosphate

4. AOAC. 2000. Official Methods of Analysis. Association of Official Analytical Chemist $17^{\text {th }}$ ed. Washington DC.

5. Yadav D N, Thakur N and Sunooj K V. 2012. Effect of Partially De-Oiled Peanut Meal Flour (DPMF) on the Nutritional, Textural, Organoleptic and Physico Chemical Properties of Biscuits. Fd Nutr Sci 3: 471-76.

6. Bansal P. 2013. Development of value added products with peanut flour for nutritional and health benefits. M.Sc. Thesis (Food and Nutrition). Punjab Agricultural University, Ludhiana, Punjab.

7. Aziah N A A, Noor M A Y and Ho L H. 2012. Physicochemical and organoleptic properties of cookies incorporated with legume flour. Intl Fd Res 19(4): 1539-43.

8. Ndife J, Kida F and Fagbemi S. 2014. Production and quality assessment of enriched cookies from whole wheat and full fat soya. European J Fd Sci Technol 2(1): 19-28.

9. Rahim A, Khalam H H, Emara S A and Sokkary H. 2004. Utilization of stevia extract in biscuits. Egypt J Agril Res 92: 1787.

\section{How to cite this article:}

Amarjeet Kaur and Anita Kochhar. 2017. Sensory and Proximate Analysis of Value Added Bakery Products Using Bael (Aegle marmelos) and Stevia Powder. Int.J.Curr.Microbiol.App.Sci. 6(12): 3749-3760. doi: https://doi.org/10.20546/ijcmas.2017.612.432 